\title{
Basin Evolution Palispatic Model of Bonaparte Basin, Australia Northwest Shelf
}

\author{
Nomensen Ricardo, Hendra Amijaya, and Salahuddin Husein \\ Department of Geological Engineering, Faculty of Engineering, Gadjah Mada University, Yogyakarta, Indonesia
}

\begin{abstract}
This research area is located on the Australian NW Shelf close to the western edge of the Sahul Platform. This research is aimed to generate the palispatic basin model of Bonaparte Basin, Australian Northwest Shelf. It is to predict the impact of Neogene collision on the petroleum system distribution on Australian Northwest Shelf. The main data used in this research are seismic data using qualitative method analysis. The well data is used to well-seismic tied. After data acquisition, the seismic data are interpreted based on the horizon and structure interpretation. These interpretation are to reconstruct the basin evolution thorough geologic time. According to data analysis, the basin evolution palispatic model are divided into Paleo-proterozoic, Paleozoic, Triassic, Early Jurassic, Middle Jurassic, Late Jurassic, Early Cretaceous, Late Cretaceous, Early Eocene, Late Miocene and Recent condition. Regional tectonically there are at least three important events in NW Shelf: Middle Triassic-Jurassic NNE-SSW extension phase, Late Jurassic NE-SW extension phase and the Neogen collision phase; the Neogen collision effects on Northwest Shelf Australia. These three events contributed in forming and disturbing the Paleozoic and Mesozoic petroleum system in Bonaparte basin especially.
\end{abstract}

Keywords: Neogene collision · Basin evolution · Palispatic model · Petroleum system · Australian northwest self.

\section{INTRODUCTION}

Australian Northwest Shelf consist of 4 major basins: the Northern Carnavon Basin, the Offshore Canning Basin, the Browse Basin and the Bonaparte Basin or unitedly known as the Westralian Superbasin / WASB (Yeates et al., 1987), which is a field producer Large gas (reaching $84 \%$ of total Hydrocarbons) in addition to condesate and oilThere were 754 exploration drilling had bored at 233 Oil and Gas Fields in Australian North West Shelf basins.Australian Northwest Shelf basin is estimated containing an oil reserve of 2.6 billion barrels, a condensate of 2.6 billion barrels and $152 \mathrm{tcf}$ of gas.

The Sahul Platform, the northern part of Australian basin, is defined as a large eastward trending basement that consists of tilted fault

\footnotetext{
*Corresponding author: N. RICARDO, Department of Geological Engineering, Gadjah Mada University. Jl. Grafika 2 Yogyakarta, Indonesia. E-mail: nomensen.ricardo@gmail.com
}

blocks and horst. This platform plunges towards the Southwest. The thin sediments of Perm, Triassic and Jurassic were deposited on Sahul Platform and progressed to the northeast. It is estimated that this platform was formed due to Paleozoic openings that later rejuvenated and lifted during the continental breakup event in Mesozoic and followed by a plate collision of Australia with microplate Southeast Asia at the end of Cenozoic. Two great Jurassic Deposits to the Early Cretaceous identified in the Northern Bonaparte Basin, Malita Graben and Sahul Syncline. The collisions of the Australian and Eurasian Plates in the Miocene to the Pliocene resulted in a flexural down warp on the Timor-Tanimbar Trench and resulted in the reactivation of the Northwest Western Australian Margin.

The study area is located on the Australian NW Shelf (Figure 1) close to the western edge of the Sahul Platform. To the north, the area is 
bounded by the Timor Trough with a NE-SW trend. At thepresent day the Australian plate is being subducted beneath the SE Asian margin and the northwestern part of Australia is currently in collision with the Banda Arc in the area around Timor Island (Hamilton, 1979).

These studies have utilised predominantly 2D seismic data and have been concerned with petroleum exploration. The area discussed in this study is relatively understudied in comparison. The main focus here is the structural configuration and an understanding of structural evolution of the northern Bonaparte Basin.

\section{Methodology}

The seismic lines of 11602 and 11609 are used to generate the basin history / evolution - section through geologic time. Both of these lines intersect each other and have a reliable marker of Flamingo Well. All horizons we have are elaborated using flattening features on Decision Space Geoscience (DSG) Software. As the result, we have the model of the basin and its development from basement (Paleo-Proterozoic) to recent sequences. Seismic cross section used is 2D seismic which has medium to good quality. Mistie adjustment is also done before beginning the interpretation of the seismic cross section. Reliable section is used as a reference for mistie analysis. Based on the results of this analysis, some vintage should be shifted and adjusted to the vintage reference.

All visible structures and horizons are interpreted based on seismic section through time geologic. Each horizon has a unique geologic event. The product of these horizon and structure is a subsurface map. The Triassic time is the focused sequence in this research. The flattening applied that are useful in basin evolution reconstruction. All horizons flatten at each time to show the change of basin geometries.

\section{Regional GeOlogy}

Metcalfe (2006) has explained in detail the evolution of the Australian Northwest Shelf basin. The initial phase of regional extensions are associated with the major aulacogenic rift, Bonaparte Graben (Petrel Sub-Basin), which developed during the Middle Paleozoic (Gunn, 1988; O'Brien et al., 1993). Although the Bonaparte rifting phase is recognizably older than the old- est rocks in Banda Forearc, extrapolation to the northwest of the Australian Margin Graben system passes through West Timor and this aulacogen clearly has a strong influence in the sequence of structural development at subsequent riftings. The second phase of rifting spanned the Late Carboniferous-Early Permian continuing throughout the Permian, to the early mid Triassic. This rifting phase is associated with the development of an intracontinental rift along the Southern Banda Band (TimorTanimbar) line, with the North Banda Busur (Buru-Seram) Island which is the northern rift margin. The third phase of openings occurs at the End of the Triassic. The major rifting phase is identified between the late Mid Jurassic and Early Cretaceous. It had been well documented by Pattillo and Nicholls (1990); Colwell et al (1994). This rifting phase is associated with the opening of the ocean floor that occurs during Oxfordian and Valanginian and continues with the development of the Indian Ocean and the passive continental margin of Western Australia.

The intra-Valanginian regional unconformities showed the absolute top of the pre-breakup sequences around the Banda arcs, though postbreakup succession is partially equivalent to the Late Jurassic on the northern Banda Arc (Audley-Charles et al., 1979; Kemp and Mogg, 1992). While pre-breakup succession is characterized by sedimentary rock deposited in a rifted continental margin environment, Banda Forearc post-breakup succession is characterized by deep sea sediments that are deposited on the outer shores of Australian continental. The marine sediment (range in Cretaceous to Tertiary) has the potential to contain hydrocarbons. The Perm rifting phase until the Early Triassic / Medium is the most significant developing structure, leading to the modification/evolution of the graben basin and intervening in the height of the horst block. As already mentioned, the northern and southern Banda Arcs developed as a complementary rifted margin during this period.

\section{Results AND Discussion}

\subsection{Horizon interpretation}

Horizon interpretation defines as identifying the sequence/strata using geologic time datum. 


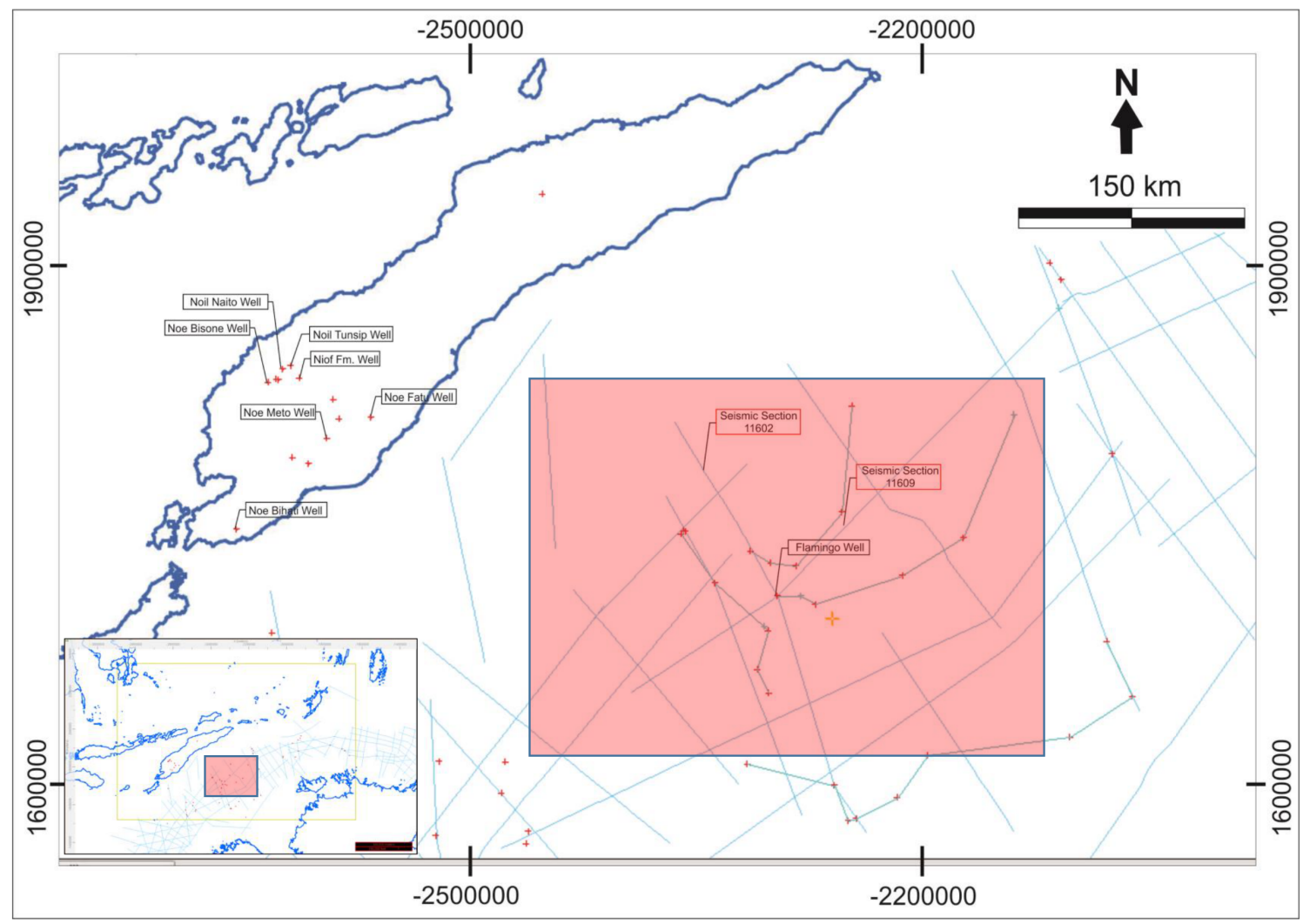

Figure 1: Basemap of research area: Australian Northwest Shelf.

The datum is distributed to other seismic section to estimate the development of strata laterally to the unknown/ unexplored area or sometimes call as stratigraphy seismic. Furthermore, the stratigraphy seismic is difficult to apply to Northwest Shelf Australia - Timor and Tanimbar island geologic setting. The geology structures developing in this research area are very complex and complicated. Some horizons interpreted are seismic section of 11602; 11603, 11608 and 11609. These section are representation of all seismic that interpreted for subsurface mapping. Totally, there are more than 30 line seismic are interpreted. But some of them are not necessary. The limitation of well data and the distance of seismic line to Timor-Tanimbar area are considered in determining/ selecting seismic line used in this research. In this term, a Flamingo well that located in Northwest Shelf Australia, is the only one trusted time geologic marker used and applied to seismic section. Seismic section NW-SE 11602 and NE-SW 11609 across the Flamingo well. These two seismic section are much more analyzed than others. According to the published paper (e.g., Longley et al., 2002), the lowest strata/ sequence that is penetrated by Flamingo well is
Middle Jurassic (Callovian) sequence. That is consistent to well-seismic tied analysis which shown Jurassic (middle) is the oldest sequence penetrated by Flamingo Well in Sahul Syncline, NW Shelf Australia. Applying Flamingo well marker, so the seismic section of 11602 and 11609 are interpreted as shown on Figure 2. The horizon picking was accomplished at some geologic time from Proterozoic to recent condition. They are grouped into, Paleozoic sequence, Triassic, Early Jurassic, Middle Jurassic, Late Jurassic, Early Cretaceous, Late Cretaceous (Turonian), Early Eocene, Late Miocene, Recent. At Early Paleozoic, sediment filled the rift basin and directly underlying Proterozoic basement. The Triassic sequence overlying on Paleozoic sequence as a post-rift sediment infilling. Triassic sequence overlying on Paleozoic sequence as a post-rift sediment infilling. At the late Triassic as a Maximum flooding surface is identified (Longley et al., 2002). This sequence is dominated by fine clastic sediments. The new structure identified at SE side on seismic section. The early Jurassic sediment filled the rift basin as an early syn-rift sediment. The Late Jurassic sediment is the beginning of post-rift/ sagging phase. Early cretaceous sediment as a 
part of postrift/ sag basin (or continuing of Late Jurassic sediment) is overlied on Jurassic sediment. Turonian sequence infilling caused subsidence in southeast part of section. Pliocene to Miocene sequence developed as a sag of carbonate sequence. A thick carbonate formed on Pliocene to Miocene interval. Carbonate Sequence dominated in Pliocene and still developed in recent time. These all horizon seismic geometry through geologic time are correlated to tectonic event in forming/ depositing sediments.

\subsection{Structure interpretation}

According to structure interpretation, three major tectonic events with different fault trend directions have been identified in the research area that associated with the Mid-Triassic extensional phase, Late Jurassic-Early Cretaceous rifting and breakup event, and the Neogene collision between Australia and the Banda Arc. The explanation of the structure configuration is described below according to the big event through geologic time.

\section{Middle Triassic extensional phase}

Based on observations from the seismic lines, this extensional phase produced normal faults that cut the Early Triassic to Permian sequence with displacements of more than $200 \mathrm{~ms}$. The faults predominantly trend NNE-SSW. The timing of the fault movements is estimated to be younger than Early Triassic and older than Middle Jurassic. Thick Triassic to Middle Jurassic sediments are interpreted from the isochron map of Permian to top Middle Jurassic horizons, and suggests that this extensional phase created a large depocentre in the northeast of the study area. In extended regions, basement fabrics commonly influence the development of faults in the region, so it is possible that the trend of the Middle Triassic faults reflects Paleozoic structural fabrics which controlled the fault geometry. Segmented faults with relay ramp transfer zones were developed at this time.

\section{Late Jurassic-Early Cretaceous rifting}

The extensional phase in the Early Mesozoic ultimately initiated the breakup event in the Late Jurassic. Displacement in the Jurassic was approximately half that of the earlier extensional phase. It created accommodation space that was filled by Late Jurassic syn-rift breakup sediments. Breakup was associated with the formation of Jurassic oceanic crust. The Late Jurassic normal faults predominantly trend E-W to ENE-WSW with steep to moderate angles of dip. The faults are believed to curve around to a NE-SW direction. Tilted fault blocks developed in the northwest of the study area with faults dominantly dipping to the NW suggest ductile deformation at the Triassic level during rifting. A low relief accommodation zone formed in the eastern graben, striking NE-SW along an en echelon array of segmented rift faults. Another rift segment also developed in the southwest of the study area with no development of an en echelon array or accommodation zone. The Middle Triassic and Late Jurassic faults appears that older fabrics strongly influenced the development of this structure. The accommodation zone in the eastern graben overlies the depression that was created by the previous extensional phase. This accommodation zone was also oriented in a similar NE-SW trend, suggesting that movement occurred on the older faults. The interpreted extension direction is perpendicular to the strike of the faults. The extension direction is consistent with the orientation of the fracture zones formed in the Jurassic oceanic crust. The interpretation also supports different extension directions for the Early Mesozoic and Late Jurassic events

\section{Neogene collision}

The Mesozoic faults was reactivated by the Australia-Banda Arc collision in the Neogene. There is a complex vertical linkage of faults in the Cretaceous-Paleocene interval. In general, the faults trend NE-SW and have a net normal displacement. The faults cut the Paleocene to approximately Upper Pliocene strata with significant development of growth strata in the Pliocene. This suggests that the faulting started during the Early Pliocene. In some places the faults die out in a significant distance below the sea floor, suggesting Late Pliocene cessation of fault activity. Selective reactivation of the faults also occurred in this region. The dip direction of the Mesozoic rift faults does not influence the younger structures.

The en echelon fault arrays located in the southern part of the study area that dipping to the southeast, linked to Mesozoic rift faults 

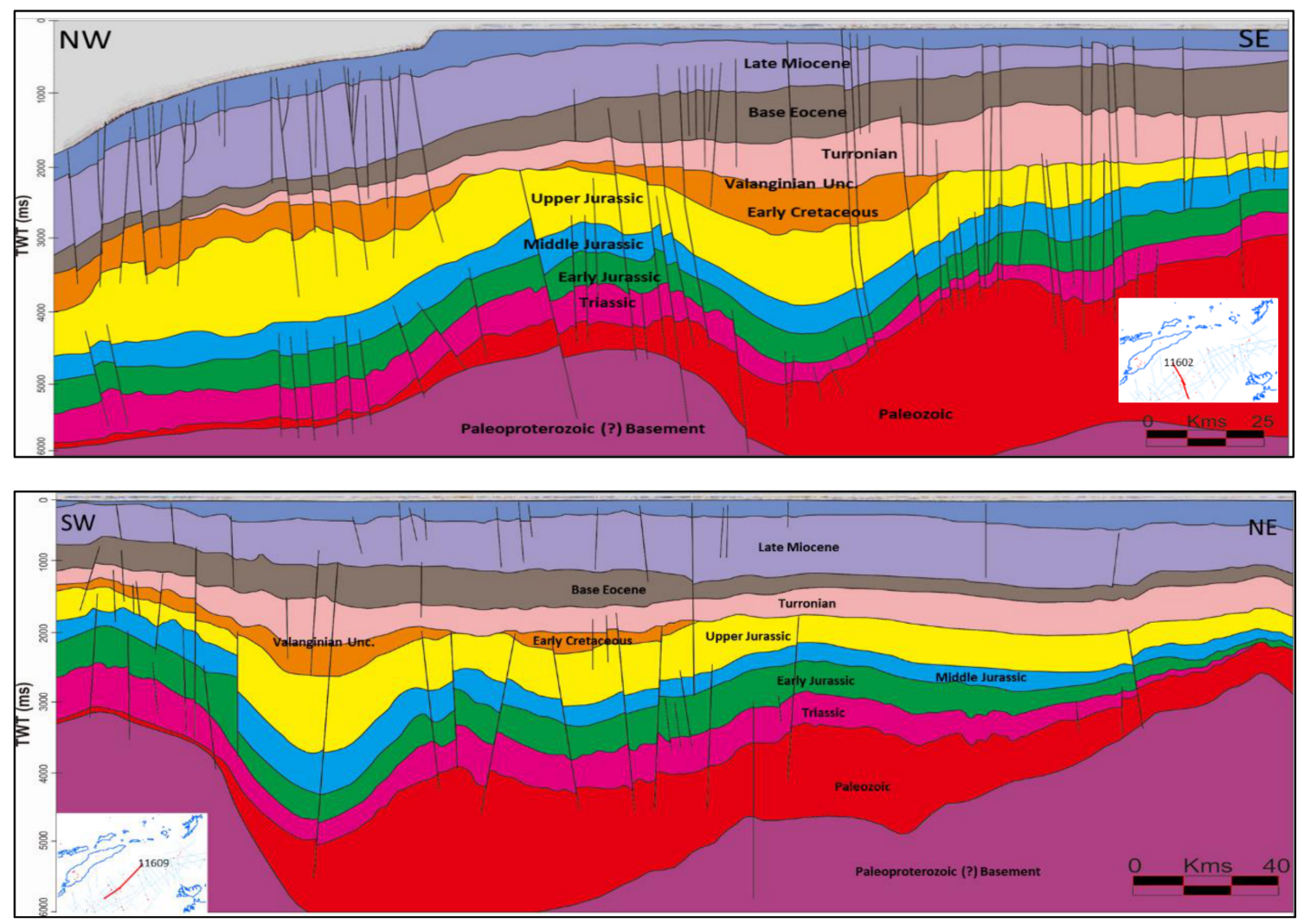

Figure 2: Seismic interpretation of seismic-lines 11602 and 11609.

with similar dip direction, whereas in the northern part of the study area the opposite is the case. Conjugate fault structures are well developed in the area where a narrow horst block was formed by the Late Jurassic rifting. Right-stepping en echelon fault arrays developed most likely in response to oblique convergence between Australia and SE Asia. The oblique motion also favoured the reactivation of the Early Mesozoic faults (Amir et al., 2010). The faults that cut the Permian and Triassic sequence also cut the syn-rift and postrift sequence, suggesting that the older fault plane was favoured for being re-used by the latest applied stress direction in the Neogene. However, not all older faults were reactivated, which may be due to the thick overburden of the post-rift packages that prevented the fault to propagate easily. No rifting occurred in the Neogene and the development of the extensional fault systems at this stage are not caused by stretching.

In the Late Miocene the continental-oceanic transition reached the subduction system and collision of the Australia and Banda Arc began at approximately $\sim 4 \mathrm{Ma}$ in the Pliocene
(Audley-Charles, 2004; Hall, 2002) and ultimately led to Timor over-thrusting the continental Australian plate, forming the Timor Trough fore-deep and later back-thrusting north of the Banda Volcanic Arc. This suggests that there are two possible mechanisms that contributed to structural development in the early Pliocene, which are flexure induced by the Timor thrusting and loading, and/or oblique convergence along the margin. The initial fault development in the study area was induced by flexure after the Australian continent reached the subduction system and collided with the Banda Arc. The collision led to the fore-deep Timor Trough development with southward thrusting of the Australian margin. The Australian continental margin was evidently bent due to loading by thrusting on Timor. This probably induced uplift of part of the Australian margin and caused some erosion of the upper crust. This may have provided sediment to the Pliocene growth sequence that filled the accommodation space during progressive development of extensional faults related to flexure. The uplift due to compression in the study area would be concentrated at a 
lower interval such as the Mesozoic. Uplift was concentrated on several horst blocks within the area.The flexural mechanism alone is not sufficient to explain the oblique displacement on right-stepping en echelon fault arrays, the splay fault development, and the reactivation of NNE-SSW trending Early Mesozoic faults observed in the study area (Barber, 2003). The interpretations of the Late Miocene structural configuration during collision, the relative plate movements at $\sim 5 \mathrm{Ma}$ and present day suggest flexure and oblique convergence were both influences. Loading due to Timor thrusting created near-surface extensional fault systems and uplift of Mesozoic horst blocks due to compression in the middle-deeper part of the crust caused linkage to deeper faults. Oblique convergence created right-stepping en echelon fault arrays trending NE-SW.

\subsection{Basin evolution}

The basin evolution of NW Shelf Australia through geologic time (Paleo-Proterozoic time to recent condition) are summarized as below.

\section{Initial basement Paleo-Proterozoic (?)}

Building block formed during Proterozoic (Barber, 2003). This block become the first main basement of Northwest Shelf Basin (Western Australia Superbasin/ WASB). According to geochronology data and provenance study, it can estimated this basement rock mainly formed of metamorphic rock (?), shown on Figure 3. It cannot identify the structure configuration. But In Timor, based on field study by Sawyer et al., the basement rocks are uplifted and outcropped to the surface area. The affinity of basement rocks that outcrop on Timor is not well understood. Schists, phyllites, amphibolites, and associated serpentinites of the Mutis/Lolotoi Complex (van West, 1941; Rosidiet et al., 1981). The basement in Timor is compositionally similar to the Mutis/Lolotoi, on the basis that Mutis/ Lolotoi lithologies were associated in the field with Maubisse Formation and Kekneno Sequence, and both contained accessory minerals similar to the Mutis/Lolotoi Complex.

\section{Paleozoic time}

At Early Paleozoic, sediment filled the rift basin and directly underlying Proterozoic basement.
This rifting have a pronounced NW-SE structural orientation (Barber, 2003). The seismic interpretation shown the normal fault is dominantly as a product of rifting phase that interpreted to have a trend NE-SW orientation. This structure formed of Carboniferous-Permian as Barber (2003) mentioned. Five times of rift occurred during Late Carboniferous-Permian Extensional episode (Etheridge and $\mathrm{O}^{\prime}$ Brien). Longley et al. (2002) identified there 3 cycles sag and syn-rift along early Paleozoic to Permian, shown on Figure 4. The NW-SE orientation rifting caused the forming of the great half-graben and some local sub-basin. The thick Paleozoic sediments filled the basin. By intensively block faulted (normal fault) and gravity effect causing subsidence event at this time. It caused basement uplift at the southern part of this section. The up and down arrows show how the tectonic and gravity effect produce the relatively movement of the basement (block faulted). Barber et al (2003) suggested that the Paleozoic event was the progenitor key rifting episode that led to subsequent progressive Mesozoic continental breakup and related thermal sag cycles. In addition, the Palaeozoic basins could contain high quality and mature oil-prone source rocks of Cambrian, Devonian and Carboniferous age.

\section{Triassic time}

Triassic sequence overlying on Paleozoic sequence as a post-rift sediment infilling. At the late Triassic as a Maximum flooding surface is identified (Longley et al., 2002). This sequence is dominated by fine clastic sediments. The new structure identified at SE side on seismic section. Besides, also a fold geometry is identified that interpreted as reactivation fault of older normal fault. Longley (2002) stated this structure as Fitzroy movement inversion occurred at late Triassic, The Fitzroy Movement period of compression in the Middle-Late Triassic resulted in reactivation and inversion of the previous Paleozoic fault systems ( $\mathrm{O}^{\prime}$ Brien et al., 1993; Colwell and Kennard, 1996) and caused widespread uplift and erosion on the Ashmore Platform, Londonderry High and in the southern Petrel Sub-basin. Upper Triassic-Lower Jurassic fluvial sedimentation deposited the Malita Formation. This was followed by the thick, widespread succession of 


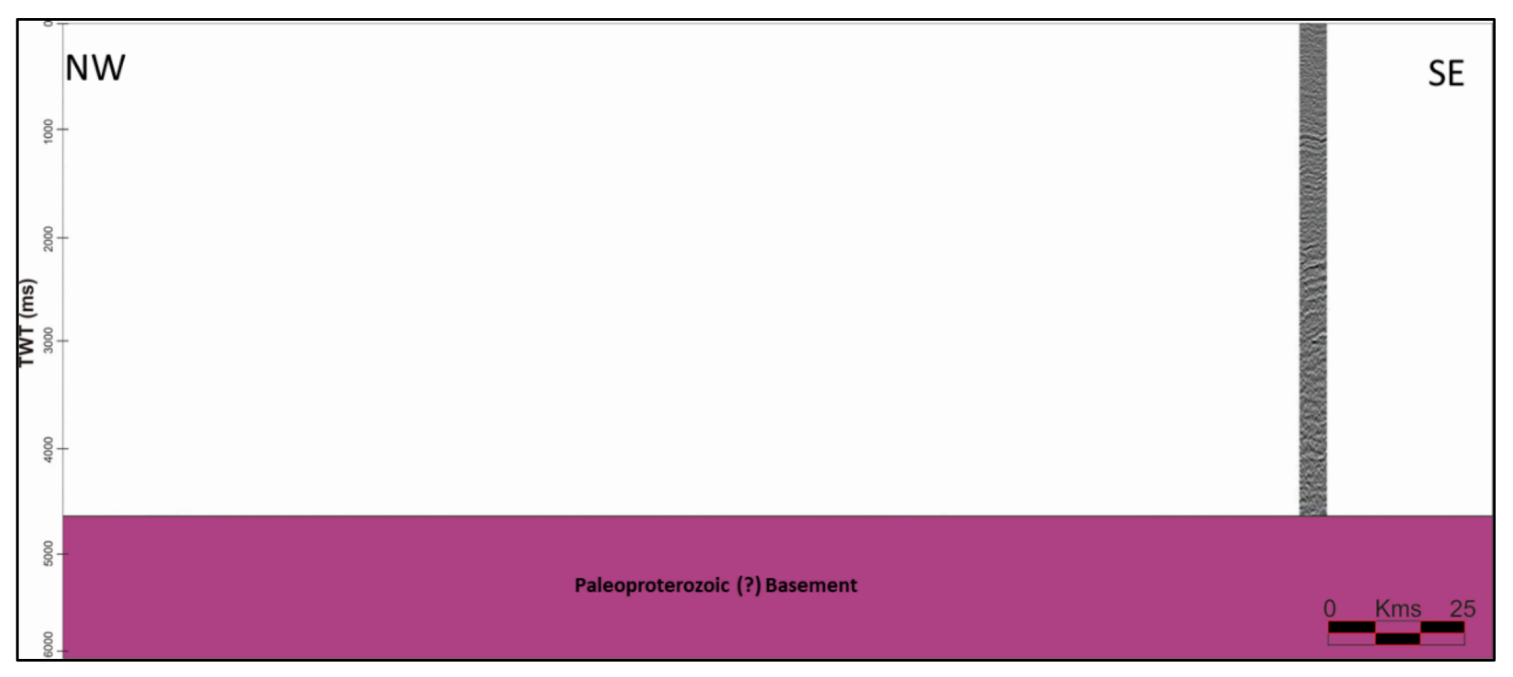

Figure 3: Flattening of Paleo-Proterozoic basement top.

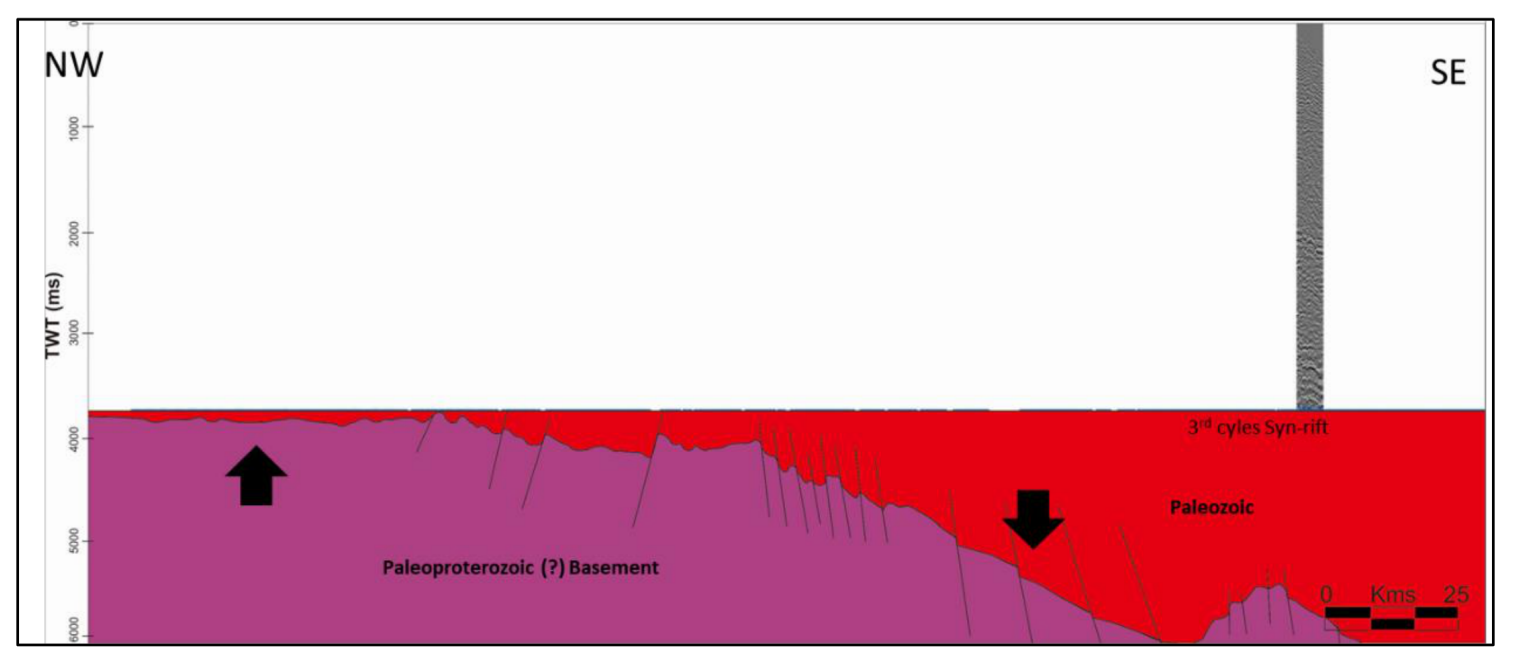

Figure 4: Flattening of Paleozoic top. 
Lower-Middle Jurassic fluvial and coastal plain deposits of the Plover Formation across most of the Bonaparte BasinAs shown by Figure 5, the Paleozoic sequence and also Triassic sequence that had been deposited are disturbed by Middle to Late Triassic compression. The structures that developing at this time caused inversion and uplifted event. The up-arrow shows the uplift itself. These uplifted area is related to surface process (e.g. erosion, transport, and deposition).

\section{Early Jurassic time}

From Triassic section to Jurassic section, occurred very deep subsidence that is identified as rifting phase after post-orogeny in late Triassic. This related to Lhasa and West Burma separation and rifting (Longley, 2002).The early Jurassic sediment filled the rift basin as an early syn-rift sediment. Continental to shelfal marine sedimentation continued throughout Early-Middle Jurassic times, leading to deposition of the Malita Formation red beds and overlying Plover Formation fluvio -deltaic sediments up to 1500-2000 m thick The Plover formation sedimentation patterns during Plover Formation times were dominated by a series of widespread braided trunk river systems feeding a relatively narrow wave-dominated coastline and beyond, a wide marine shelf (Barber, 2003). Although the major structures are extension/ rifting, the reactivated structure is believed still occurring at this time. Seismic evidence (Figure 6) shows the inversion structure identification. The other new fault also found on this section. The early Jurassic time produce good reservoir (e.g. Plover Formation) that experienced complex and complicated structure. It is indicated by the contradictive structure found. At rifting phase, it still possibly found the inversion structure (uplifted area) in local area especially on the middle area of this section. The left-right arrow shows the extension fault, while down-arrow shows the basin forming/ subsidence as shown on Figure 6.

\section{Middle Jurassic time}

This section shows the continuing deposition of the syn-rift sediment, which the sediment Mid-Jurassic was deposited over early Jurassic sediment. The Continental to shelfal marine sedimentation continued from Early Juras- sic (as explained above) to Middle Jurassic times, leading to deposition of the Malita and overlying Plover Formation (fluvio-deltaic sediments). Plover Formation times were dominated by a series of widespread braided trunk river systems feeding a relatively narrow wavedominated coastline and beyond, a wide marine shelf (Barber, 2003).In response to southwest to northeast diachronous breakup Callovian to Oxfordian (Middle Jurassic), local depocentres such as the Malita and Calder Graben developed, heralded by a marine transgression (Laminaria/Elang Formation sands). The shoreline was initially in the same position as the preceding Plover succession but began to move inboard as basinal deepening andr elated sediment starvation continued, the sands being replaced by condensed shales (Frigate Shale).The normal fault is clearer identified on this section. Then drag fold can be seen in given location. The basement on NW side little bit uplifted. It can be interpreted as a flexuring event, where the voluminous sediment supply filled the basin depocenter, so it caused uplifting in basement high as shown on Figure 7.

\section{Late Jurassic time}

Further subsidence continued in these depocentres during latest Tithonian to early Cretaceous times (Barremian), with deposition of over 500-1500m of marine shales and turbidite sands of the Upper Flamingo Group. By this time, the palaeo-shoreline had receded some $120 \mathrm{~km}$ towards the craton, inducing starved argillaceous facies over much of the area, excepting for occasional turbidite sand. These sands were derived from the continually flowing Goulburn Graben axial trunk river system, as observed by pronounced incised channeling of late Tithonian age which penetrated channel fill clays. The final stage of starved sedimentation in the Upper Flamingo led to the preservation of enriched marine organic shales in condensed sequences of the Echuca Shoals Formation.According to Figure 8, the Upper or Late Jurassic sediment is the beginning of post-rift/ sagging phase (partially sag). Further subsidence continued in the depocentres during Upper Jurassic. Longley et al. (2012) stated that the basin filled by marine shale and turbidite sands. On this section, the basement uplifted as thick sediment filled depocenters which causing flexuring on base- 


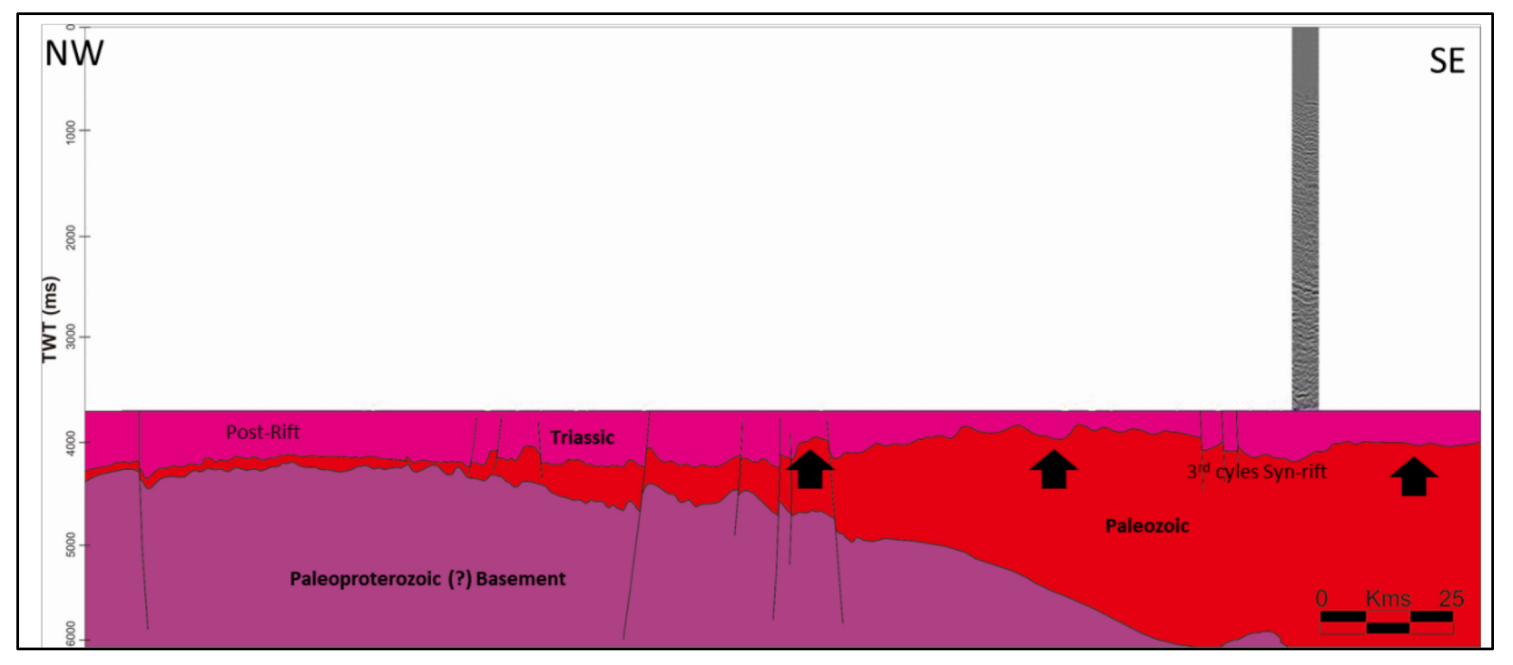

Figure 5: Flattening of Triassic top.

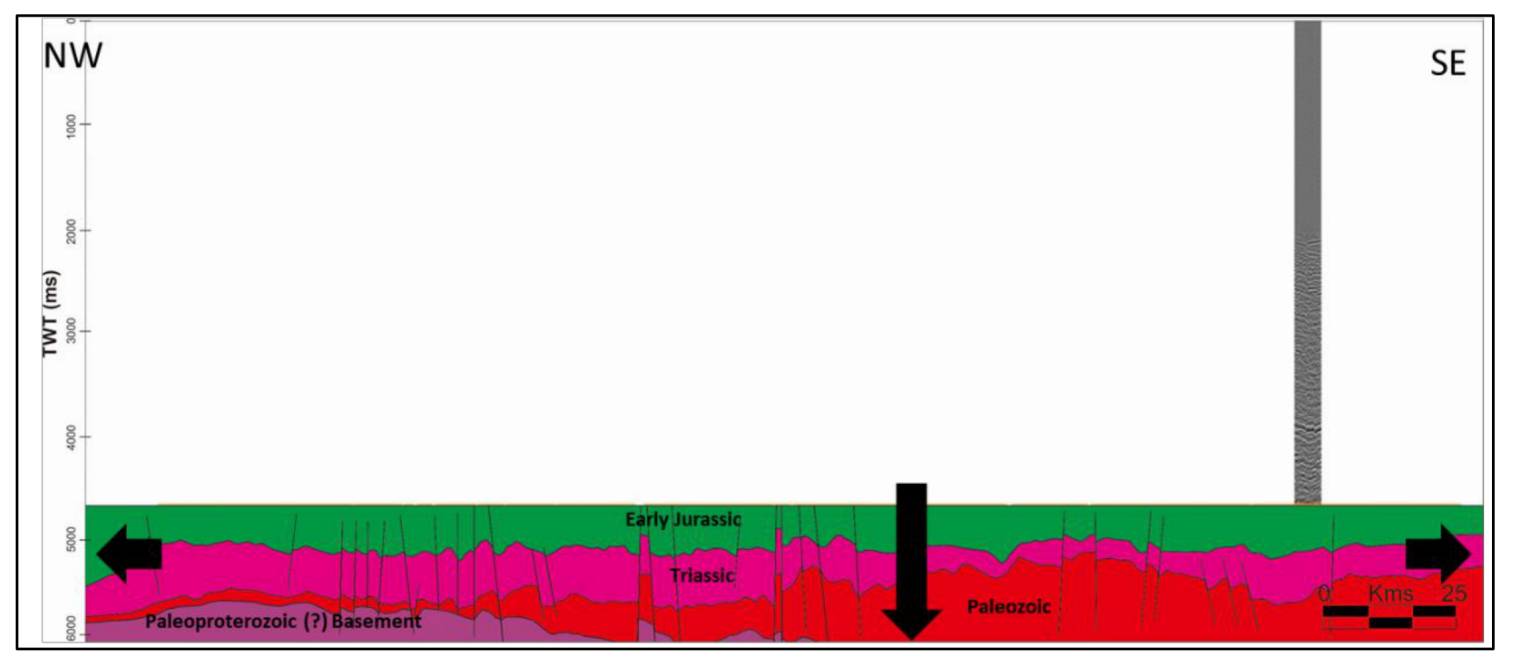

Figure 6: Flattening of Early Jurassic top.

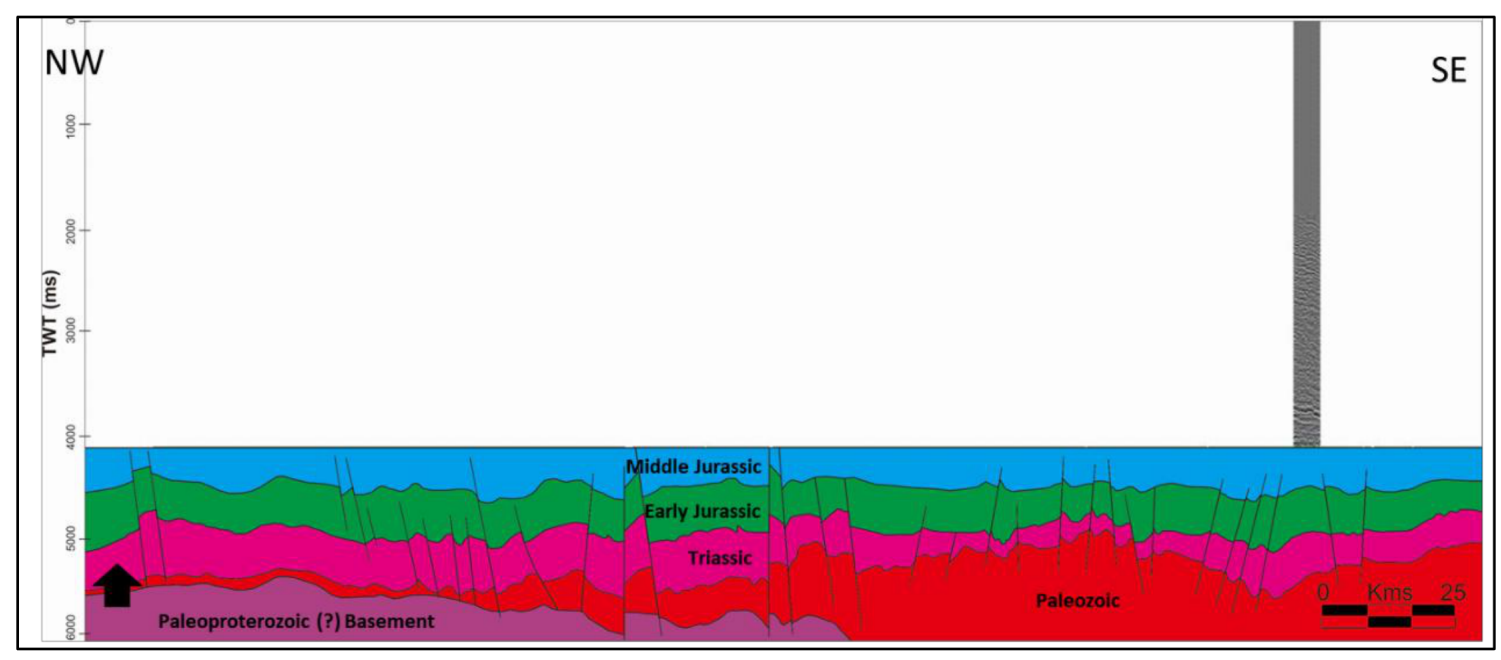

Figure 7: Flattening of Middle Jurassic top. 
ment highs. The main structures developing on this time is normal fault that cut upper Jurassic sequence.

\section{Early Cretaceous to Valanginian time}

Early cretaceous sediment as a part of postrift/ sag basin (or continuing of Late Jurassic sediment) is overlied on Jurassic sediment. Compression tectonic identified on this section. It's shown by anticline/fold geometry that was formed and some dragging folds found as caused by compression. In this section, the Jurassic Sequence uplifted and then a part of sequence was eroded by surface process. This erosion occurred in Valanginian, shown on Figure 9. The succeeding intra-Valanginian unconformity marks the beginning of the final post-breakup subsidence phase and commencement of pronounced thermal sag and passive margin cooling. The succession is characterized by deposition of fine grained clastics of Mid to Late Cretaceous age, deposited in an aggradational to progradational shelf slope environment, interrupted by occasional lowstand events especially in the Late Campanian, sands being derived from the Goulburn Graben proto-river trunk stream.

\section{Late Cretaceous time}

Continuing the sediment deposition of the Early Cretaceous, at Late Cretaceous age, also deposited in an aggradational to progradational shelf slope environment, interrupted by occasional lowstand events especially in the Late Campanian, sands being derived from the Goulburn Graben proto-river trunk stream.Turonian sequence overlie on early Cretaceous and to Southwestward Turonian sequence overlie on Jurassic Sequence on this section. Turonian sequence infilling caused subsidence in southeast part of section. It also caused flexuring. Normal fault structure developed intensively. Some research stated that Turonian is a mark of maximum flooding event in Cretaceous event that known as a thick seal and broadly distributed or called as regional Seal, shown on Figure 10. During the Late Cretaceous, uplift of the hinterland (in response to rift events along the Australian southern margin), resulted in a phase of inversion. This tectonic event marked the onset of transpressional structural growth of pre-existing rift related structures. Further the hinterland uplift resulted in a block rotation of the margin (where sediments inboard of the tilt line were eroded and redeposited into deeper water environments (Longley et al., 2002).

\section{Early Eocene time}

Early Eocene sequence overlie on Turonian sequence. Eocene sequence is believed as the late second phase of sagging event (after Turonian sagging event) on open marine passive margin condition. In other words, this sequence is bounded by maximum flooding surface. The subsidence occurred but not significant. Normal fault developed and cut early Eocene sequence, shown on Figure 11. Further sand influxes into the Caswell and southern Vulcan areas occurred in the Maastrichtian, and following the base Tertiary onset of Coral Sea spreading, the North West Shelf had moved sufficiently far north for carbonate factories to be established in areas away from clastic input (Longley et al., 2002). Following a major plate reorganisation in the middle Eocene, Australia moved rapidly northwards, and carbonate deposition became dominant (Baillie et al., 1994). Reworking of carbonates from the factory tops led to massive carbonate progradation, infilling the underfilled accommodation space provided by the underlying rift basins.

\section{Late Miocene time}

After Eocene MFS, Pliocene to Miocene sequence developed as a sag of carbonate sequence. A thick carbonate formed on Pliocene to Miocene interval. Carbonate sequence developed on early Eocene sequence. Late Miocene event is important, because it is identified as beginning of compressive orogeny that reactivated the older fault (inversion structure). This section shows significant uplifting, shown on Figure 12. The identified collision in the Neogene reactivated older Mesozoic faults. The faults cut the Paleocene to approximately Upper Pliocene strata with significant development of growth strata in the Pliocene. This suggests that the faulting started during the Early Pliocene-Late Miocene. The Late Miocene horizon can be considered as representative of the structural configuration in the Neogene (Figure 12). In some places the faults die out in a significant distance below the sea floor, suggesting 


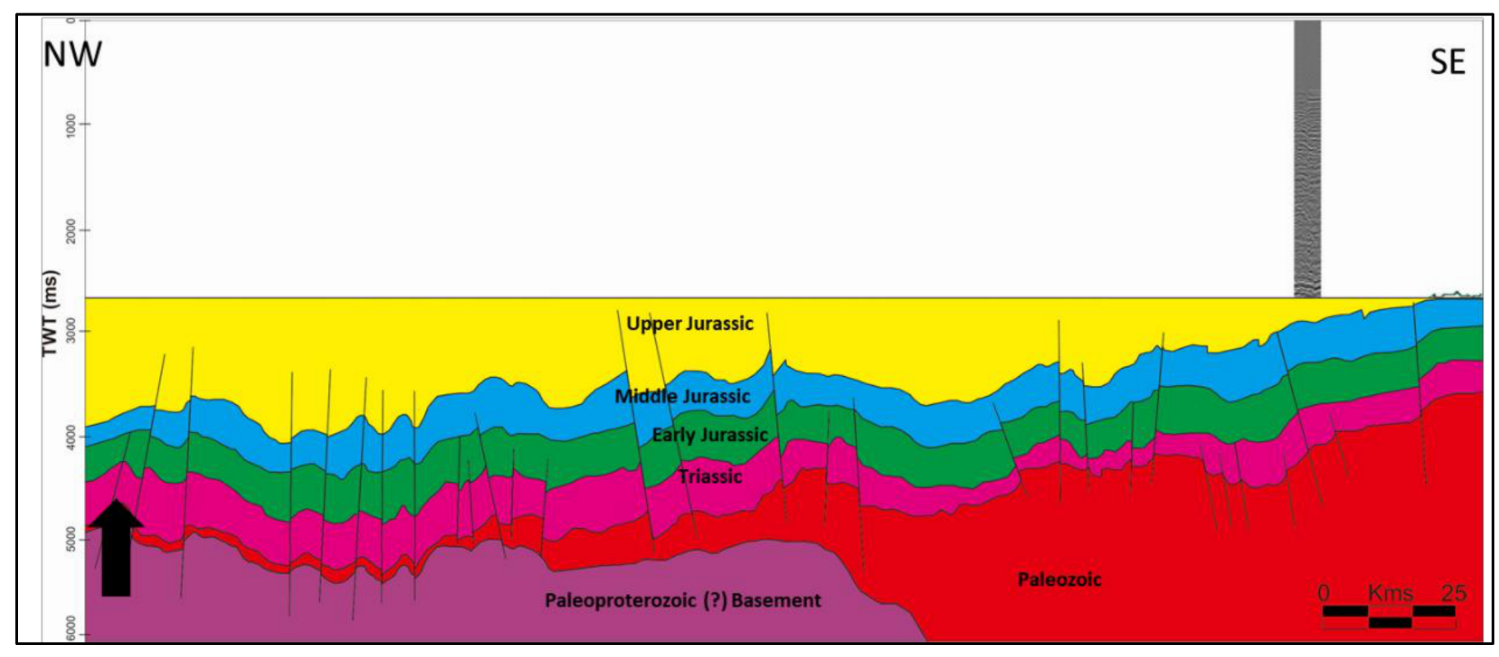

Figure 8: Flattening of Late Jurassic top.

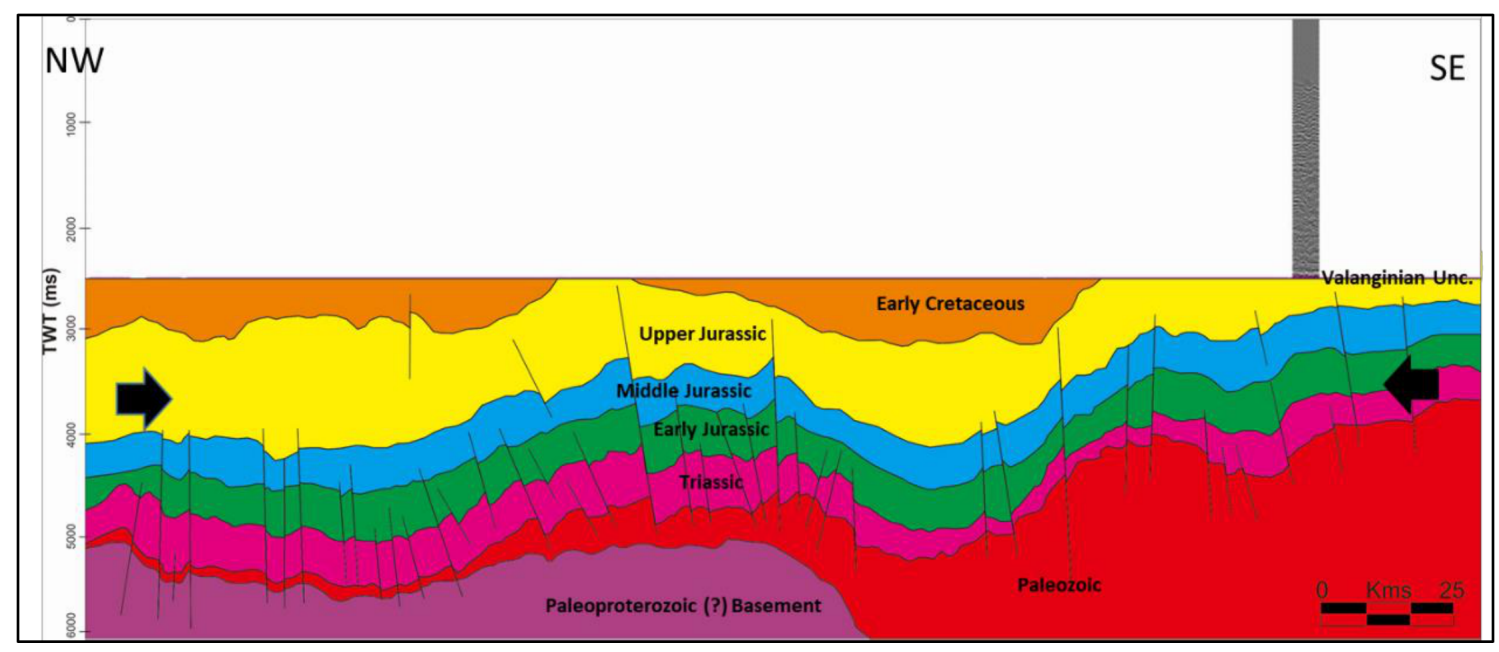

Figure 9: Flattening of Early Cretaceous top.

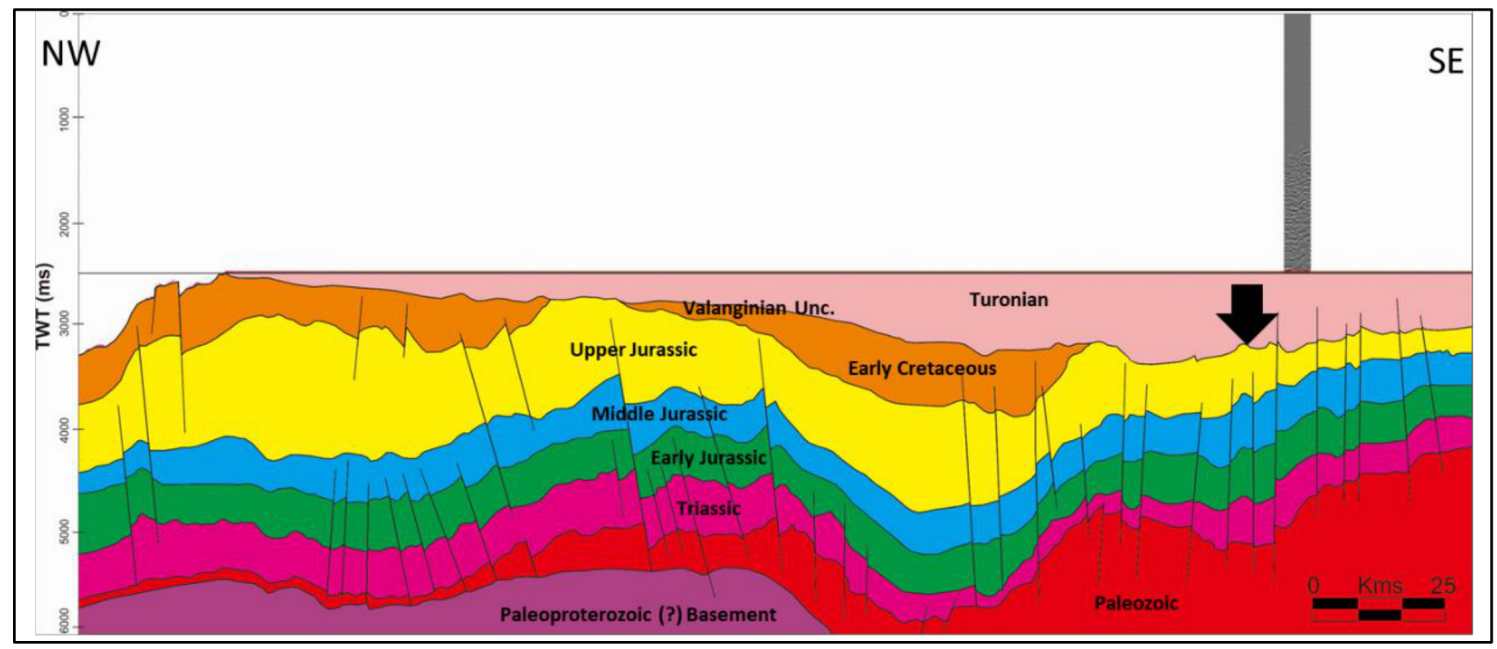

Figure 10: Flattening of Late Cretaceous top. 


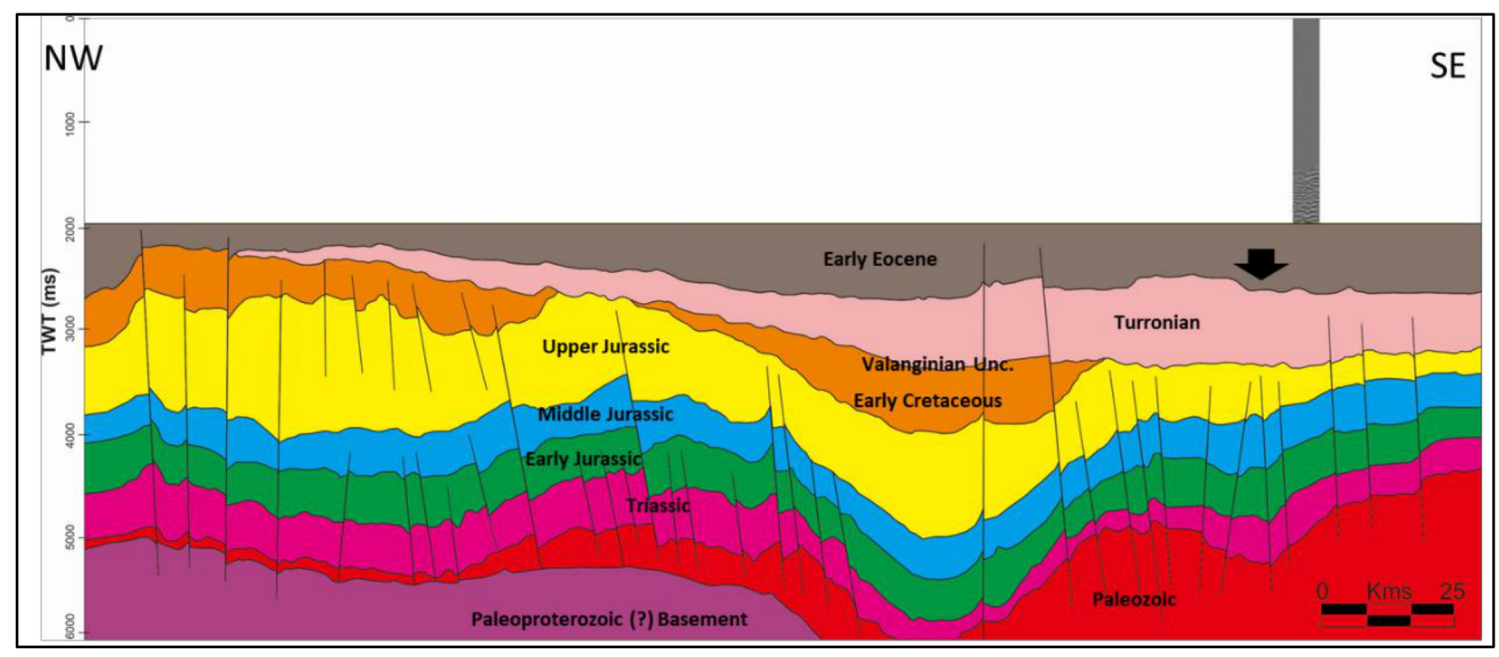

Figure 11: Flattening of Early Eocene top.

Late Pliocene cessation of fault activity. Selective reactivation of the faults also occurred in this region. The dip direction of the Mesozoic rift faults does not influence the younger structures. This is clearly shown by the en echelon fault arrays located in the southern part of the study area that dipping to the southeast, linked to Mesozoic rift faults with similar dip direction, whereas in the northern part of the study area the opposite is the case.

\section{Recent condition}

Pliocene age is the peak of compressive event that triggered by oblique strike-slip fault. This event related to curvilinear arc accretionary prism and Timor-Tanimbar Trough as a consequence of Neogene Australian continental plate collision with Indonesia arc system. The structure associated with compression and strike-slip developed especially in Miocene to Pliocene sequence. Carbonate Sequence dominated in Pliocene and still developed in recent time, shown on Figure 13. Amir et al. (2010) suggested that the interpretations of the Late Miocene structural configuration during collision, the relative plate movements at $\sim 5 \mathrm{Ma}$ and present day, and the stress map of the region suggest flexure and oblique convergence were both influences. Loading due to Timor thrusting created near-surface extensional fault systems and uplift of Mesozoic horst blocks due to compression in the middle-deeper part of the crust caused linkage to deeper faults. Oblique convergence created right-stepping en echelon fault arrays trending NE-SW.

\section{CONCLUSION}

The basin evolution palispatic model represents the structure contributions in petroleum system that formed in Sahul Platform, Bonaparte Basin, Australian Northwest Shelf. This model divide the geologic events based on the geologic time such as Paleo-proterozoic, Paleozoic, Triassic, Early Jurassic, Middle Jurassic, Late Jurassic, Early Cretaceous, Late Cretaceous, Early Eocene, Late Miocene and Recent condition. Regional tectonically there are at least three important events in NW Shelf: Middle TriassicJurassic NNE-SSW extension phase, Late Jurassic NE-SW extension phase and the Neogen collision phase; the Neogen collision effects on Northwest Shelf Australia. These three events contributed in forming and disturbing the Paleozoic and Mesozoic petroleum system in Bonaparte basin especially.

\section{ACKNOWLEDGEMENTS}

We thank STEPS-Halliburton Program for providing the dataset. Nomensen Ricardo's Graduate Programme at Universitas Gadjah Mada was made possible by this research programme who have supported the projects in Indonesia. We thank Helen Smith, Jamie Higton and Colette Lyle (from STEPS Halliburton) for supervision, discussion and help and the 2016's Magister programme of Geological Engineering Department students for support.

\section{REFERENCES}

Amir, V., Hall, R., and Elders, C.F. (2010) Structural Evolution of Northern Bonaparte Basin, North- 


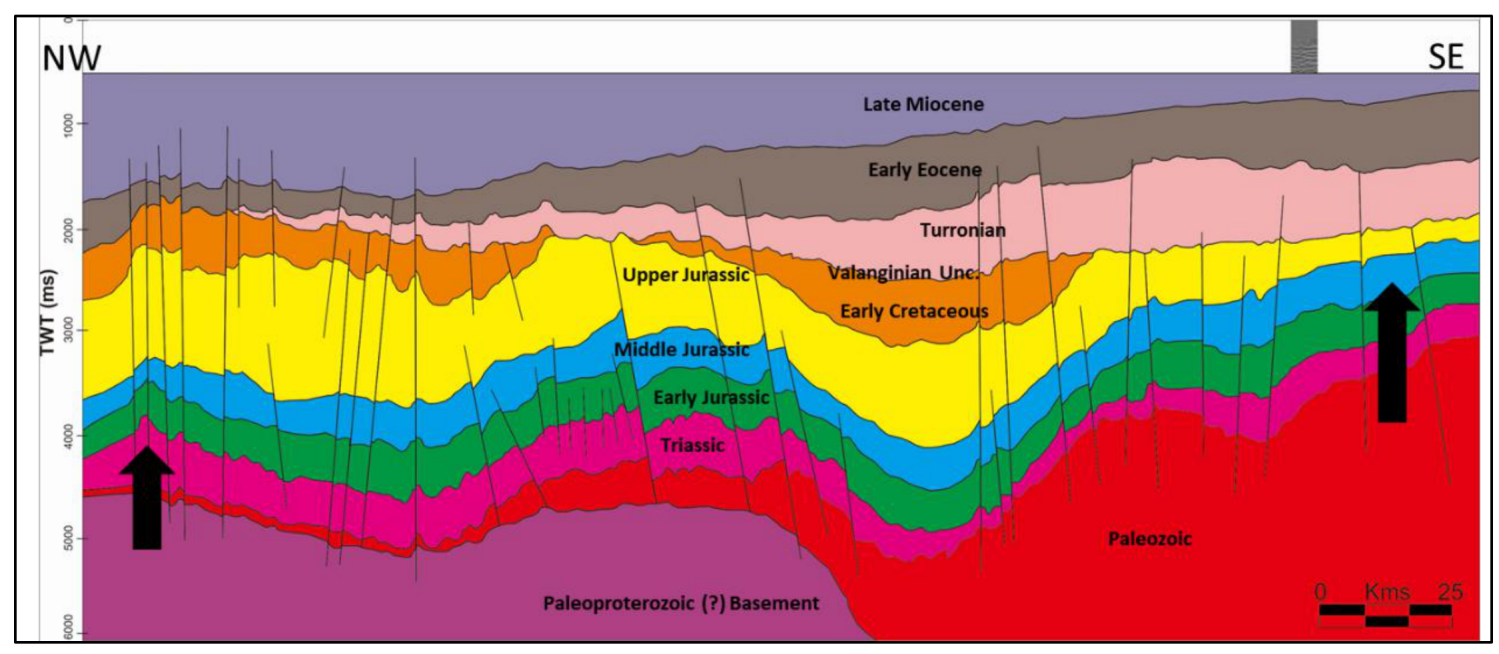

Figure 12: Flattening of Late Miocene top.

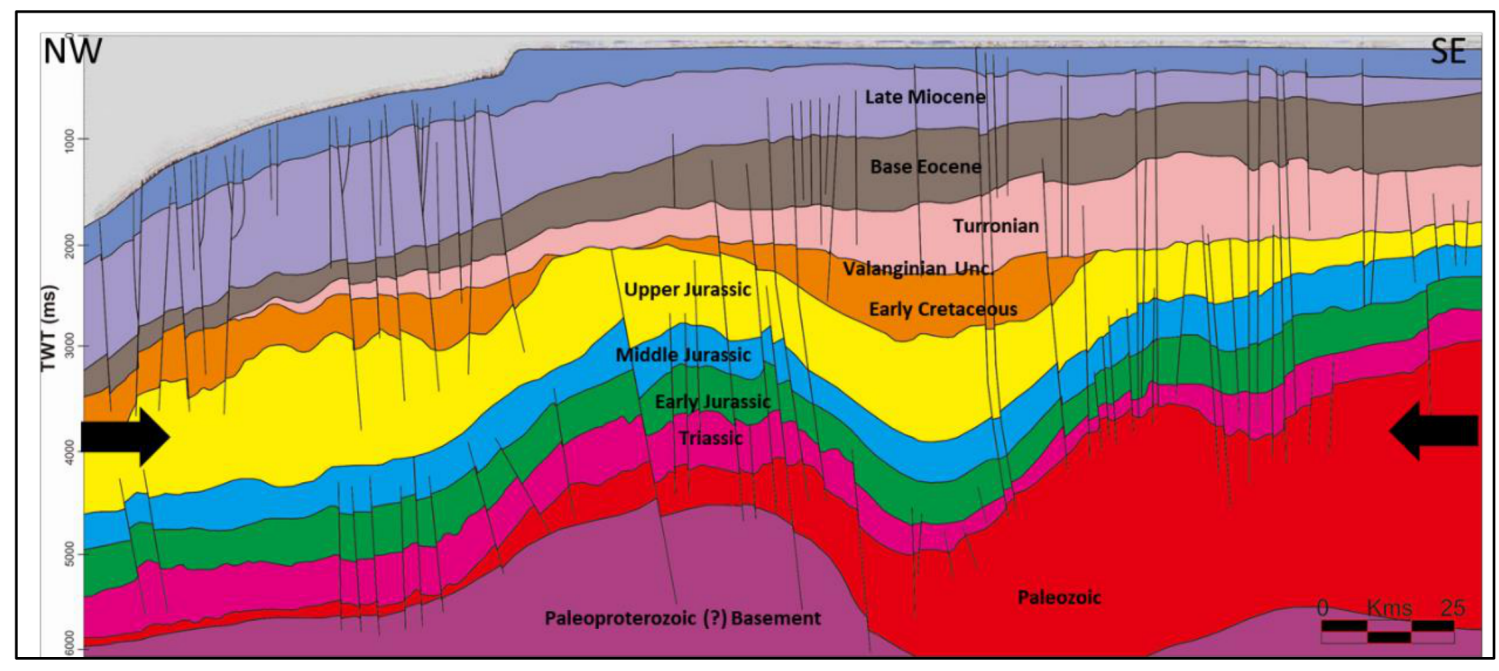

Figure 13: Flattening of recent condition. 
west Shelf Australia. Proceedings of the Indonesian Petroleum Association $34^{\text {th }}$ Annual Convention. IPA Annual Convention Proceedings, p. 117 (IPA10-G-201).

Audley-Charles, M., D. Carter, A., Barber, M., Norvick, and Tjokrosapeotro, S. (1997) Reinterpretation of The Geology of Seram: Implications for The Banda Arcs and Northern Australia, J. Geol. Soc. London, p.547-568.

Audley-Charles, Ballantyne, P.D., and Hall, R. (1988) Mesozoic-Cenozoic rift-drift sequence of Asian fragments from Gondwanaland, In: C.R. Scotese and W.W. Sager (eds.), Mesozoic and Cenozoic Plate Reconstructions. Tectonophysics, 155.

Barber, P., Carter, P., Fraser, T., Baillie, P. and Myers K. (2003) Paleozoic and Mesozoic Petroleum Systems in the Timor and Arafura Seas, Eastern Indonesia. Proceedings of the Indonesian Petroleum Association $29^{\text {th }}$ Annual Convention. IPA Annual Convention Proceedings no. 1, p. 116. (PIDBB_023115).

Charlton, T.R. (2002) The Petroleum Potential of East Timor. APPEA Journal (Australian Petroleum Exploration Association Journal), v. 42, no. 2, p. 351369. (ZURBB_000007).

Charlton, T.R., Barber, A.J., McGowan, E. Roniewicz, Cook, S.E., Barkham, S.T. and Bird P.R. (2009) The Triassic of Timor: Lithostratigraphy, chronostratigraphy and palaeogeography. Journal of Asian Earth Sciences, v. 36, no. 4-5, p. 341-363. (XURBB_419134).

Colwell, J.B., Symonds, P.A. and Crawford, A.J. (1994) The nature of the Wallaby (Cuvier) Plateau and other igneous provinces of the West Australian margin. AGSO Journal of Australian Geology and Geophysics, 15(1).

Dickinson, W.R. (1974) Plate Tectonic and Sedimentation. In Dickinson, W.R. (ed.), Tectonic and Sedimentation. Society of Economic Paleontologist and Mineralogist special publication 22: 1-27, Tulsa.

Dickinson, W.R. and Suczek, C.A. (1979) Plate Tectonics and Sandstone Compositions, AAPG Bulletin 63: 2164-2182.

Earl, K.L. (2006) An Audit of Wells in the Arafura Basin, Geoscience Australia Record 2006/02, p.1448-2177.

Gunn, P. J. (1988) Bonaparte basin: Evolution and structural framework, in Purcell, P. G., and Purcell, R. R. (eds.) The North West Shelf Australia: Proceedings of Petroleum Exploration Society Australia Symposium, Perth, 1988, W. A. PESA, p.401-409.

Longley, I.M., Buesseschuett, C., Clydsdale, L., Cubitt, C.J., Davis, R.C. Johnson, M.K., Marshall, N., Murray, A.P., Somerville, R., Spry T.B. and Thomson N.B. (2002) The North West Shelf of Australia
- A woodside perspective. In M. Keep and S. Moss (eds.), The Sedimentary Basins of Western Australia. Petroleum Exploration Society of Australia (PESA), Special Publication no. 3, p. 28-88. (ZURBB_019852).

Metcalfe, I. (2006) Palaeozoic and Mesozoic tectonic evolution and palaeogeography of East Asian crustal fragments: The Korean Peninsula in context. Science Direct, 24-26pp.

Mitchell, A.H.G and Reading, H.G. (1987) Sedimentation and Tectonics. In Reading, H.G. (ed.), sedimentary environment and facies, pp. 439-476, Oxford: Blackwell Scientific Publications.

Nagura, H., Suzuki, I., Teramoto, T., Hayashi, Y., Yoshida, T., Bandjarnahor, H.M.P., Kihara, K., Swiecicki, T., and Bird, R. (2003) The Abadi Gas Field, Proceedings $29^{\text {th }}$ Annual Convention of the Indonesian PetroleumAssociation, p.1-16.

Neftex (2017) NEFTEX Exploration Insights: Enterprise Solutions and Reservoir Decisions, Landmark Halliburton Company.

O’Brien, G.W., Etheridge, M.A., Willcox, J.B., Morse, M., Symonds, P., Norman, C. And Needham, D.J. (1993) The Structural Architecture of The Timor Sea, North-Western Australia: Implications for Basin Development and Hydrocarbon Exploration. The APEA Journal, 33(1).

Ohara, M., Nakamura, K. and Sasaki, Y. (2015) The Structural Evolution of Babar-Selaru Region in the Southern Banda Outer Arc, Eastern Indonesia. Thirty-Ninth Annual Convention and Exhibition. IPA Annual Convention Proceedings no. IPA15G_180, p. 1-17. (XURBB_588329).

Otis, R. M. and Shneidermann, N. (1997) A Process for Evaluating Exploration prospects. AAPG Bul., 81, 7 (July), 1087-1109.

Pattillo, J. and Nicholls, P. J. (1990) A tectonostratigraphic framework for the Vulcan Graben, Timor Sea region. APEA J, p.176-194.

Purcell, P. G. and Purcell, R. R., eds. (1988) The North West Shelf Australia: Proceedings of Petroleum Exploration Society Australia Symposium, Perth, W. A. PESA. IX - 1

Reading, H.G. and Levell, B.K. (1996) Controls on sedimentary rocks. In. Reading, H.G. (ed.), Sedimentary Environments: Process, Facies and Stratigraphy, $3^{\text {rd }}$ ed. pp.5-36. Oxford: Blackwell Science Ltd.

Reed, T.A., de Smet, M.E.M., Hamhap, B.H., and Sjapawi, A. (1996) Structural and Depositional History of East Timor, Proceedings $25^{\text {th }}$ Annual Convention of the Indonesian Petroleum Association, p.297-312.

Sani, K., Jacobson, M.I., Sigit, R. (1995) The Thin Skinned Thrust Structures of Timor, Proceedings $24^{\text {th }}$ Annual Convention of the Indonesian Petroleum Association, p. 277-293.

Shell, Ltd., LKFT UGM, and Ditjen Migas (2013) 
Joint Study Report: Offshore Timor Barat Area, Nusa Tenggara Timur, Indonesia.

Selley, R.C. (1985) Ancient Sedimentary Environments. $3^{\text {rd }}$ ed, Springer Science. 317p.

Sentani, E.A., and Nugraha, A. (2009) Kai Tanimbar, Jurnal Inameta, Patra Nusa Data.

Sawyer, R.K., Sani, K. and Brown, S. (1993) The stratigraphy and sedimentology of West Timor, Indonesia. Proceedings of the Indonesian Petroleum Association 22 ${ }^{\text {nd }}$ Annual Convention. IPA Annual Convention Proceedings no. 1, p. 533-574. (PIDBB_022691). 